\title{
ALGUNES CONSIDERACIONS SOBRE L'AUTORIA DELS VERSOS SOLONIANS
}

\author{
MARTÍ ESQUIROL DOMENECH \\ Universitat de Barcelona \\ marti.esqui@gmail.com \\ ORCID: 0000-0002-1775-543X
}

RESUM

L'objectiu d'aquest treball és presentar un estat de la qüestió partint d'allò que han dit els antics sobre l'obra poètica de Soló i, alhora, d'allò que en comenta la crítica moderna per arribar a esclarir si alguns dels versos que conservem sota la rúbrica «Soló» poden ésser considerats autèntics o han patit un procés de congriament divers.

PARAULES CLAU: Soló, elegia arcaica, fonts antigues, autoria, crítica contemporània.

\section{SOME CONSIDERATIONS ABOUT THE SOLONIANS VERSES' AUTHORSHIP}

\section{ABSTRACT}

Starting from both the ancients' interest in Solonian poetry and the different points of view of contemporary criticism, the aim of this paper is to offer a state of investigation to clarify the authorship of several Solonian verses. The problem is that some contemporary scholars consider a good few poetical fragments of the Solonian corpus inauthentic.

KEYWORDS: Solon, archaic elegy, ancient sources, authorship, contemporary criticism.

La figura de Soló, tal com assenyala Herwig Maehler (Noussia 2001: 5-6), ha estat tractada llargament pel que fa a la política, mentre que s'ha deixat de banda la seva obra poètica. I és que, efectivament, els primers estudis monogràfics dedicats a Soló d'ençà mitjan segle XX, com el de Masaracchia (1958), han posat molt més èmfasi en la dimensió política que en la poètica, per bé que per a abordar la primera tots els estudiosos moderns, talment com l'autor de l'Athenaíon Politeía i Plutarc, s'han hagut de servir necessàriament dels fragments - també poètics - conservats per reconstruir la figura de Soló.

Al primer llibre de Vides i doctrines dels filòsofs més il·lustres, Diògenes Laerci $(1,61)$ atribueix a Soló cinc mil versos, ${ }^{1}$ una xifra que a tots els estudiosos ha semblat altament improbable; amb tota seguretat, exagerada. Les anomenades

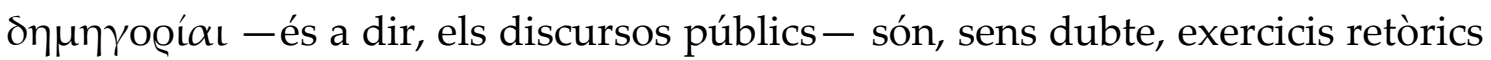

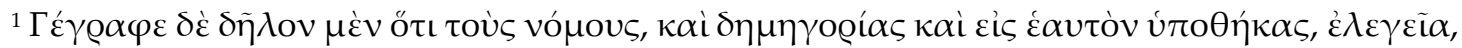

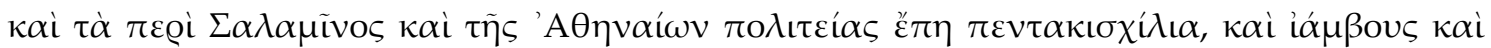
$\varepsilon \dot{\pi} \omega \delta$ oús («I va escriure, evidentment, les lleis, i parlaments públics, però també exhortacions per a ell mateix, elegies, els cinc mil versos sobre Salamina i la política dels atenesos, i també iambes i epodes». Traducció de Grau [2014]).
} 
tardans atribuïts a Soló. Potser la tradició que reporta que Soló també hauria compost epodes pretenia igualar-lo amb els altres elegíacs arcaics.

Lardinois (2006: 15-16) fa notar que, des de l'Antiguitat, hi ha tres temàtiques de fragments d'ipsissima verba atribuïts a Soló: les lleis (vó $\mu \mathrm{ol}$ ), les dites $(\gamma \nu \omega \mu \alpha \iota)$ i la seva poesia. Pel que fa al canvi de codi legal respecte al de Dracont, la figura de Soló ha interessat més als historiadors que no pas als filòlegs clàssics per raó de la seva empresa constitucional. Esbrinar quina va ser realment l'aportació legislativa soloniana ha ocupat llargament els historiadors, que s'han esforçat a dilucidar què hi ha de veritat i què hi ha de fals en les fonts antigues i en els mateixos versos de Soló. Avui dia podem afirmar, tot i que molt prudentment, que Atenes sí que devia canviar de sistema legislatiu, però sense poder precisar gaire més, perquè aquesta qüestió encara ara és tema de constant

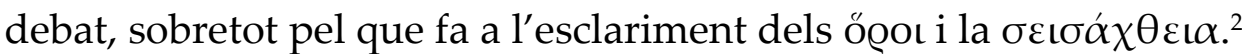

En relació amb les dites $(\gamma \nu \omega ́ \mu \alpha \mathrm{l}), \mathrm{n}$ 'hi ha moltes de les quals se li atribueixen que són recurrents a d'altres savis arcaics. Els antics el recorden com un moderat i mediador en els problemes polítics i socials de l'Atenes de tombant de segle VII-VI aC. A això, cal sumar-hi la sagacitat característica dels savis arcaics: tot un honor, perquè la tradició sempre el comptarà entre el cànon que Plató va establir de comptar-ne set.

Tanmateix, pel que fa a la poesia, en les darreres dues dècades, d'ençà que Raaflaub (1996: 1041) va apreciar que la destinació - aparentment - pública de la poesia de Soló és una peculiaritat pròpia, l'estat de la qüestió sobre els versos solonians ha canviat força. Molts dels dístics que descriuen la crisi de la ciutat o l'amenaça de lluites intestines $i$, en particular, l'avidesa de riqueses dels nobles o la relació entre la hýbris dels poderosos i la ruïna de la ciutat són objecte de constant reformulació i reciclatge dins del corpus teognideu i, per tant, es demostren «llegibles» més enllà de l'específica realitat de l'Atenes d'inicis del segle VI aC i del pensament polític de Soló, fet que demostra que haurien adquirit entre els segles VI i V aC una mena de sort "panhel-lènica», tal com creu Nagy (1990: 36-82). En la mateixa línia, Raaflaub (1996) és de l'opinió que la poesia de Soló és una síntesi generalitzant de tradicions que obvia l'especificitat política de l'Atenes del segle $\mathrm{VI}$ aC, fet que el duu a considerar-lo com una etiqueta estereotipada d'aquest tipus d'elegia política; d'aquí que proposi parlar de

${ }^{2}$ Les narracions aristotèlica (Ath. 6-9 i 10, 1) i plutarquea (Sol. 14, 3-16), tal com presenten les reformes solonianes, fan pensar en dos moments diferents: primerament, haurien estat decretades les reformes de caire econòmic i, després, les constitucionals. Així mateix ho pensen Musti (1990: 227-234) i Lane Fox (2007: 101). Plutarc afirma que el terme $\sigma \varepsilon\llcorner\sigma \alpha ́ x \theta \varepsilon\llcorner\alpha$ era un eufemisme per referir-se a la remoció dels deutes, la reforma soloniana més mediàtica. Fins i tot els antics, com Androció (Plu. Sol. 15, 3) i Aristòtil (Ath. 6, 1), creuen que fou una reducció d'interessos, però Plutarc $(S o l .15,5)$ s'entesta a adduir que la majoria (oí $\delta \dot{\varepsilon} \pi \lambda \varepsilon i \tilde{\sigma} \tau o l ~ \pi \alpha ́ v \tau \tau \omega v$ ) creu que fou una remoció absoluta ( $\chi \varepsilon \tilde{\omega} \nu \alpha \dot{\alpha} \pi о \kappa о \pi \eta ́)$. Actualment, molts historiadors com Musti (ibid.), Canfora (1986: 69-80) o Lane Fox (2007: 101) han maldat per esclarir-ne els dubtes sobre si fou o no total, però l'opinió majoritària considera que va ser com deia Aristòtil (Ath. 6, 1): una reducció quantiosa, però en cap cas una tabula rasa. 
«Soló» en lloc de Soló. Això no obstant, tant Lefkowitz (1981) com Raaflaub (1997) consideren les composicions poètiques de Soló genuïnes i que constitueixen, per tant, l'evidència més fiable de les reformes que l'atenès va dur a terme. ${ }^{3}$ Lardinois (2006: 19-32), que segueix les passes de Nagy (1985), creu que hi ha raons per a dubtar de la paternitat soloniana d'una mínima part dels fragments conservats sota la rúbrica de Soló. Així doncs, Lardinois afirma que, en el cas de Soló, també s'hauria produït el fenomen d'atribució a posteriori, que situa cronològicament entre els segles V i IV aC a Atenes, explicant, així, el mateix fenomen que es va produir amb Hesíode i Homer en la poesia èpica, i amb Tirteu, Simònides i Teognis en el cas del gènere de l'elegia.

Seguidament, comentarem quatre fragments a partir dels quals s'argumenta aquest debat entre filòlegs, que tan breument hem exposat.

\section{FRAgMents 1, 2 I 3 DE WEST ${ }^{4}$}

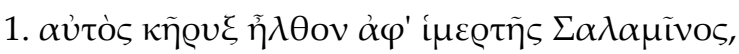

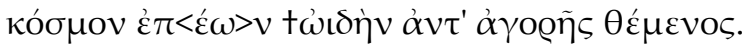

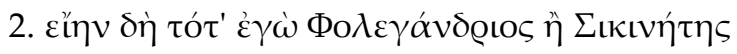

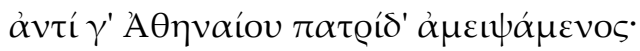

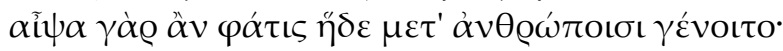

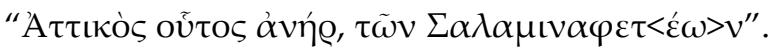

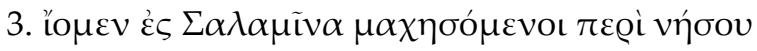

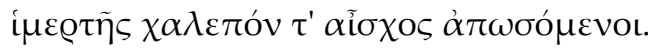

1. «Jo mateix vinc en qualitat d'herald de la nostra estimada Salamina, $i$ he compost un cant, ornament de paraules, en lloc d'un discurs». ${ }^{5}$

2. «Voldria ser de Folegandros o de Sícinos abans que d'Atenes en haver canviat de pàtria; immediatament hi hauria aquesta dienda entre els homes:

'Aquest home és àtic, dels que van abandonar Salamina'».

3. «Anem a Salamina a lluitar per l'estimada illa i per foragitar la greu ofensa».

Aquests tres fragments constitueixen el nus de totes les dissensions actuals entre els estudiosos. A l'Antiguitat, segons recull Plutarc a la Vida de Soló (8, 1-3), aquesta elegia hauria constat de cent versos i Soló l'hauria recitada a l'àgora. Ara bé, el problema que es planteja és si aquests versos són un unicum dins de totes les elegies, car Soló - sempre segons Plutarc - els hauria compost per recitar-los

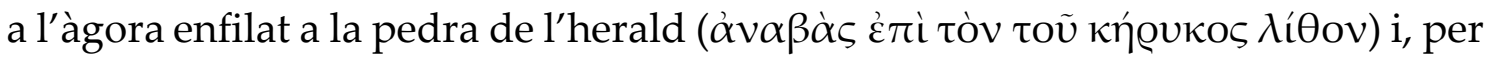
tant, fora del marc del simposi. Les discrepàncies de tots els estudiosos tenen un denominador comú: el lloc de recitació i, en estreta relació, el públic que devia

\footnotetext{
${ }^{3}$ Per a més detalls sobre les reformes i els problemes que presenten, vid. supra (n. 2).

${ }^{4}$ West (1972).

${ }^{5}$ La traducció, si no s'indica el contrari, és pròpia.
} 
tenir aquesta elegia. Mentre que West (1974: 12) afirma que caldria considerar la possibilitat que aquestes elegies fossin la publicació literària de discursos escrits en prosa, Noussia (2001: 46) només ho contempla en el cas de l'elegia Salamina. L'autora (2001: 45) argumenta que la ficció de la performance assembleària s'hauria de posar en paral·lel a l'autorepresentació fictícia i contextual de voler mostrar-se com a $\kappa \tilde{\eta} \varrho v \xi$ de Salamina (fr. 1-3 W.), alhora que es vol dotar el missatge d'una determinada oficialitat. Vetta (1996: 208) s'aventura a dir que la primera execució d'aquesta elegia intitulada Salamina, així com també la famosa elegia de les Muses (fr. 13 W.), hauria tingut lloc al Pritaneu d'Atenes. Tedeschi (1982) emmarca tota la producció poètica de Soló en el simposi i creu que el públic és sempre la seva étaı@é́ $\alpha$. Finalment, segons Lardinois, l'obra va ser atribuïda a Soló de manera tardana (vers el segle $\mathrm{V} \mathrm{aC}$ ). ${ }^{6}$

\section{FRAGMENT 31 DE WEST}

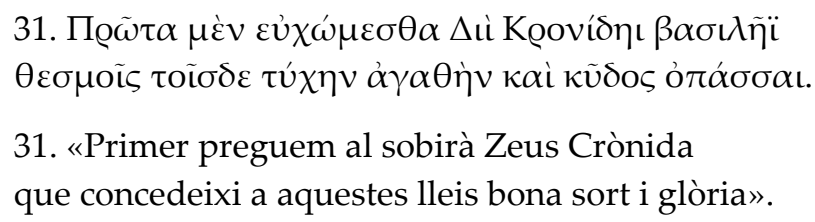

Aquests dos versos són considerats unànimement espuris per la crítica recent, és a dir, que, tot i que figuren entre les seves composicions a les edicions dels seus versos, en realitat no ho són. Els estudiosos Gerber (1999) i Noussia (2001) així ho creuen perquè el mateix Plutarc (Sol. 3, 5) posava en dubte que

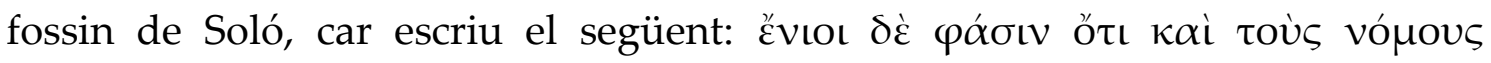

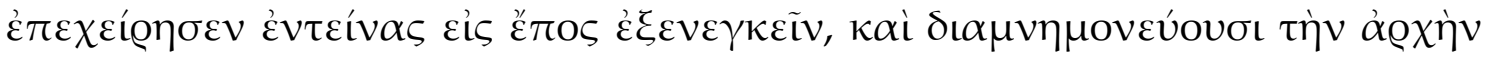

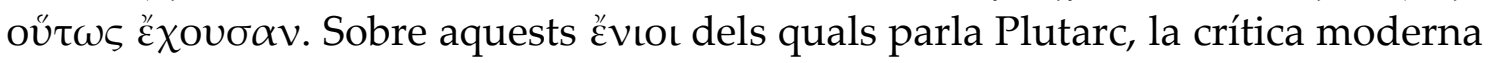
(Noussia 2001: 385-386) manté el dubte que té l'autor de Queronea a l'hora de reportar la notícia i la jutja dubtosa. Manfredini i Piccirilli (1977) creuen haver detectat la font d'aquesta notícia, atès que consideren que es tracta d'Hermip d'Esmirna, el Cal·limaqueu.

En fi, hem mirat de resseguir alguns dels punts més debatuts sobre els quals la crítica moderna dissenteix i que han dut a qüestionar a diversos estudiosos la paternitat de determinats versos. Entre aquests investigadors es compta Lardinois (2006) que, amb una proposta recent força interessant, presenta comparativament els versos que conservem de Soló i els que aporten fonts antigues diverses. Tant l'Athenaíon Politeía com Teognis i Plutarc presenten versos lleugerament modificats, cosa que porta a Lardinois a afirmar que la poesia de Soló s'hauria transmès indubtablement de manera oral, però que l'atribució a

\footnotetext{
${ }^{6}$ Lardinois (2006: 17): «The conquest of Salamis (together with this elegy?) may have been assigned to the older statesman $[\ldots] »$.
} 
aquest autor és només convencional i que, en cap cas, els seus versos es poden considerar autèntics.

\section{BIBLIOGRAFIA}

CANFORA, L. (1986), Storia della letteratura greca, Roma i Bari, Laterza.

GERBER, D. E. (1999), Greek Elegiac Poetry, Cambridge, Loeb Classical Library.

GrAU, S. (2014), Diògenes Laerci. Vides i doctrines del filòsofs més il.lustres, Barcelona, Fundació Bernat Metge.

LANE Fox, R. (2006), The Classical World: an Epic History of Greece and Rome, London, Penguin Books (trad. de Lozoya, T. i Rabasseda-Gascón, J., El mundo clásico: la epopeya de Grecia y Roma, Barcelona, Crítica, 2007).

LARDINOIS, A. P. M. H. (2006), «Have we Solon's verses?», a Solon of Athens: New Historical and Philological Approaches, Lardinois, A.P.M.H. i Blok, J. (eds.), Leiden i Boston, Brill, 15-35.

LEFKOWITZ, M. R. (1981), The lives of the Greek poets (Classical Life and Letters), Londres, Duckworth.

MANFredini, M. i Piccirilli, L. (eds.) (1977), Plutarco. La Vita di Solone, Verona, Fondazione Lorenzo Valla i Arnoldo Mondadori.

MASARACCHIA, A. (1958), Solone. Florència, La Nuova Italia.

Musti, D. (1990), Storia greca. Linee di sviluppo dall'età micenea all'età romana, Roma i Bari, Laterza.

NAGY, G. (1990), Greek Mythology and Poetics, Ithaca i Londres, Cornell University.

NAGY, G. (1985), «Theognis and Megara: a Poet's Vision of his City», a Theognis of Megara: Poetry and the Polis, Figueria, T. i Nagy, G. (eds.), Baltimore, Johns Hopkins University, 22-81.

NoussiA, M. (2001), Solone. Frammenti dell'opera poetica, Milà, Biblioteca Universale Rizzoli.

RaAflaub, K. (1997), «Legend or Historical Personality? Solon Reconsidered», a Acta: First Panhellenic and International Conference on Ancient Greek Literature (23-26 May 1997), Papademetriou, J-Th. (ed.), Atenes, Hellenic Society for Humanistic Studies, 97-117.

RAAFLAUB, K. (1996), «Solone, la nuova Atene e l'emergere della politica», a I Greci. Storia, cultura, arte, società, 2.I. Una storia greca. Formazione, Settis, S. (coord.), Torí, Einaudi, 1035-1081.

TEDESCHI, G. (1982), «Solone e lo spazio della comunicazione elegiaca», QUUC, 10, 33-46. VETTA, M. (1996), «Convivialità pubblica e poesia per simposio», QUUC, 54 (3), 197-209. WEST, M. L. (1972), Iambi et elegi Graeci, 2, Oxford, Clarendon.

WEST, M. L (1974), Studies in Greek Elegy and Iambus, Berlín, De Gruyter. 
